\title{
THE INFLUENCE OF GENDER ON FINANCIAL DECISIONS: EVIDENCE FROM SMALL START-UP FIRMS IN SPAIN
}

\section{Carmen Maria Hernandez-Nicolas, Juan Francisco Martín-Ugedo, Antonio Mínguez-Vera}

\section{Introduction}

The study of the characteristics of shareholders and managers and their effect on various variables related to the company, mainly its value, is extensive. Among the most analyzed characteristics are the shareholder structure [84], the composition of the board of directors [1], and the combining of the positions of CEO and chairman of the board of directors in the same person [10].

One of the characteristics that has been the focus of increasing interest for researchers is the presence of women on corporate boards of directors (for a comprehensive survey on the presence of women on corporate boards of directors, see [79]). However, the presence of women on the board has become an important topic, not only for academic reasons but also for social reasons. In recent years there has been pressure from society to include women on the boards of directors. As a consequence, the average number of women in boardrooms has increased in the European Union from 5\% in 2001 to $8.1 \%$ in 2007 , but it is still a small figure.

Focusing on 2007 data, even if the gap has been reduced in recent years [36], figures are larger for the Unites States $(13.6 \%)$ and Canada $(11.2 \%)$ than for Europe. Inside the European Union there are also important differences by country. For example, Portugal is the country that has fewest women on boards with only $0.7 \%$. In contrast, Norway and Sweden have a higher proportion, with $37 \%$ and $21.3 \%$ of female directors, respectively. In Spain the presence of women in boardrooms (of IBEX-35 index firms - 35 top companies in capitalization) is about $3.1 \%$ of all directors, a figure that is similar to Italy $(2.3 \%)$ and Japan (2\%) [24].

To correct this situation several steps have been taken in Spain. In May 2006 the Comisión Nacional del Mercado de Valores, CNMV, (Spanish Securities and Exchange Commission) passed the Código Unificado de Buen Gobierno (Unified Code of Good Governance). In Article 15 , this Code recommends that the board of directors reflect the diversity of knowledge, gender and experience required to perform its functions with effectiveness, objectivity and independence. To achieve this objective, the Code suggests positive discrimination in order to balance figures for men and women on boards.

In March 2007 the Spanish parliament approved the Ley de Igualdad (Gender Equality Act). On the topic of the board of directors, this law suggests at least $40 \%$ of directors be women by 2015 , but this quota is not mandatory and merely a recommendation. However, companies that do not comply with this quota will be unable to bid for public contracts. This law came into effect the $24^{\text {th }}$ of March, 2007 and it applies to public and private firms with more than 250 employees.

The requirement that $40 \%$ of board members should be women is an imitation of a Norwegian law approved in January 2003. That law required the achievement of the quota of $40 \%$ female representation on boards in five years. Between 2003 and 2008 the percentage quadrupled to a value of $38 \%$ [37], and Norway is at the head of European countries for female representation on boards of directors.

All these rules made in Spain in the business field have focused on large companies. However, micro-enterprises and small enterprises are not only more numerous, but they are also the main engines of economic growth and employment. In Spain, on 1st January 2009, $99.88 \%$ of firms were SMEs (Central Companies Directory).

Another aspect that has attracted the interest of researchers in recent times is the presence of women as CEO [14]. Traditionally, this position has been filled predominantly by men. However, evidence has shown that firms 
whose CEO is a woman have higher levels of returns on average [82].

More participatory management styles may lead to higher returns [5], as women are more prone to cooperate with other managers [38]. Another explanation of higher returns of companies whose CEOs are women is provided by Mohr and Wolfram [56]. According to these authors, commitment to the firm and employee satisfaction in the workplace strongly influences the performance of a firm. Communication with the employees is essential to create a positive climate of trust. According to Mohr and Wolfram [56], women are more effective communicators.

Based on previous arguments, it would seem that there should be larger number of women as CEOs. However, research shows that even if the numbers of men and women in management jobs in general are relatively close, this is not the case for CEOs ([15] and [18]).

Until now, most studies on this field have focused on analyzing the effect of gender diversity on the performance of large companies [25], [32]. According to Soltane [77], the more women are on the board, the better is the performance in the company. Other studies examined legal environments, environmental factors and processes that influence entrepreneurship among women [12], [13], [49].

Research on financial decisions and their relationship with the gender of managers is very limited, especially in the field of small enterprises. These companies are especially interesting for the study of the contribution of women as directors, given that their governing bodies tend to be smaller, less structured and less complex, so that each member has a greater capacity to influence decision-making [42].

Gender may influence the level of corporate debt, as well as its cost and maturity. There are two main arguments why this should be the case. On the one hand, women often prefer to accept lower levels of risk [23], [76]. On the other hand, there may be discrimination for reasons of gender on the part of the credit supply [12], [17].

This study has several novel features. First, the firms analyzed are small, unlike the firms that provide most of the previous empirical evidence. Second, we examine companies in their first year of life (star-up firms) where the differences in preference for financing, discrimination on the part of the suppliers of funds and difficulty in accessing finance may be more evident. Finally, unlike previous papers, we discuss three variables relating to the financial structure: level of debt, debt maturity and debt cost. In addition, the Spanish market is generally thought to be part of the continental system or civil law system, in contrast with the American market, which provides most of the available evidence, and belongs to the common law or Anglo-Saxon system. The differences between the two systems are large, but can be summarised in three points: companies in the Anglo-Saxon system tend to have much more dispersed shareholder structures, there is more investor protection and the external control mechanisms are relatively strong [46], [47]. Because of these characteristics, the study of the composition of boards of directors may be more relevant in markets like Spain.

The results reveal a negative influence on firms' debt levels of the presence of women on the boards or as CEO. This negative effect can also be seen when boards are more genderdiverse. In addition, gender diversity drives toward lower costs and higher debt maturity. Therefore, it seems that risk aversion on the part of women is a better explanation for the results than discrimination on the supply side.

The rest of the paper is structured as follows. The Section One presents the theory and hypotheses. Section Two describes the sample, the data and the methodology. The results are presented in Section Three. Finally, we present the main conclusions.

\section{Theory and Hypotheses}

Financing and capital structure are one of the most examined topics in the financial literature. In 1958, Modigliani and Miller [54] published one of the most influential papers in the financial literature where they demonstrated that the leverage adopted by a firm is irrelevant in perfect capital markets [56]. After this paper, many others have examined the influence of tax considerations [26], [53], [55], financial distress [3], [6], [83], and information asymmetry and agency costs [30], [40], [59], [60]. As a consequence of these and many other papers, there exist two main non-excluding theories that attempt to explain existing firms' capital structures: trade-off theory and pecking order theory. 
The trade-off theory considers that each firm has an optimal debt level that may be reached balancing the advantages and disadvantages of market imperfections (mainly taxes, costs of financial distress, and agency costs and information asymmetry).

Pecking order theory was first modelled by Myers and Majluf [60]. Myers and Majluf consider that the empirical evidence is not consistent with a financial policy that is determined by a trade-off of the advantages and disadvantages of market imperfections [60]. Rather, companies' financial policies seem to be better explained by the behaviour described by Donaldson [29]. He establishes a hierarchy describing company preferences for internal financial sources over external financial sources; in the case of external financial sources, a company prefers debt first, then hybrid instruments like convertible bonds, and finally equity issues.

However, trade-off and pecking-order are not the only relevant theories related to capital structure. Another influential theory is the financial growth cycle theory [7]. According to this theory, there are several variables that influence the level of information asymmetry in companies, and the age and the size are amongst the most important ones.

Normally, older companies are considered to have lower levels of information asymmetry. This is due to the fact that older companies are considered to be more consolidated and external investors know about the company's situation [27], [85]. On the other hand, young companies, and especially start-ups, present higher economic growth and opportunities. This could imply new investment projects and thus larger information asymmetry.

Size may also reduce the information asymmetry. This is because large companies are less risky, as they are usually more diversified [67], [69], [83]. Larger companies also produce more accounting and financial information for creditors and investors in general [31], so that it is less costly to control them.

Several papers, among which is the one by Berger and Udell [7], establish the explanation that companies finance themselves in different ways depending on the phase they occupy in their financial growth cycle. The main sources of external financing for small start-up firms are commercial credits and (short-term) bank loans. Some of the empirical implications of the financial growth cycle have already been tested in the Spanish market [73].

Several papers that follow this line of study conclude that the size of a company is a factor that influences not only on the availability, but also the maturity and the cost, of credit for companies [65], [66], [74]. Small enterprises have more problems securing long-term and low-cost funds [80]. The problems arising from the existence of asymmetry of information mean that financial institutions cannot properly assess their borrowers' investment projects (adverse selection problem), or control their opportunistic behaviours (moral hazard problem).

In addition, large companies may negotiate favorable access to various types of financial sources, since they have more tangible assets that can be used as collateral [33]. This implies that small enterprises have trouble accessing finance, and are consequently left with the limited choices of self-financing [22], the investment of money of the owners (or family) [64], [72], [81] and (short term) borrowing.

Focusing on diversity, group diversity is defined as the variety of individual attributes within a group [8]. Most arguments related to information/decision-making theories predict a positive influence of diversity on group outcomes. Thus, Robinson and Dechant [70] argue that greater diversity in working groups implies a better knowledge of the market and a better identification with customers and employees, thereby increasing the company's ability to penetrate markets. Similarly, the more diverse a group is, the more different views and perspectives its members will have, as well as more alternative solutions to a problem, leading to more realistic decisions being taken [57].

However, there are also arguments that increased diversity may have negative effects on group outcomes. These arguments come from social identification and social categorization theories. According to these theories, individuals divide the group members into in-groups (individuals similar to themselves) and out-groups (individuals dissimilar to themselves), having a tendency to perceive the former positively and the latter negatively [61].

Gender diversity is part of group diversity and it may also have an influence on firm behaviour. As an example, Loden [50] argues that women are qualitatively oriented while men are oriented quantitatively, an argument which could support the belief that women are 
more successful in some specific tasks. Thus, women directors may exert a positive influence on the firm in tasks related to corporate social responsibility and strategic control. In contrast, the presence of women on the board may have a negative influence, as they may have fewer relationships with boards of other firms [86], and are less likely to have business occupations [45].

With regard to financial decisions, the different level of risk aversion between men and women may be extremely important. Many papers provide arguments and evidence to show that women tend to prefer a lower level of risk [76], [41], [11], [23], [63], [20], [75]. As an example, it seems that women entrepreneurs tend to run smaller companies and their firms are more concentrated in the service sector [20], [44], [51]. They also tend to run firms that have lower debt levels, which may be because they try to reduce the costs of bankruptcy and are reluctant to provide the necessary guarantees to obtain a loan [19]. Romani et al. [71] also find that women invest less money in their businesses and expect lower returns than men.

However, lower levels of debt in enterprises run by women may also be explained by other factors related to gender such as discrimination on the part of credit suppliers [58]. There is evidence that the decisions of the banks about loan requests are different for men and women, even when businesses are similar in terms of liquidity and solvency. Buttner and Rosen [16] found that banks perceive that men have more probability of business success than women. Other papers show that gender discrimination not only appears in the final decision of granting of credit but also throughout the application and negotiation process, placing women at a disadvantage or discouraging them during that process [12], [75].

These arguments (greater risk aversion among women and discrimination on the part of the supplies of credit) may influence not only the level of debt of firms, but also the cost and maturity of debt. Thus, a higher cost of debt in companies where women participate in management would be a clear sign of discrimination, while a lower cost could be seen as evidence that the participation of women in management reduces the risk to the company and thus the cost of financing. Similarly, a longer term of maturity of debt in companies managed by women would be a sign of their greater risk aversion [62].

Although there are conflicting arguments, based on the discussion in the literature we present three hypotheses:

Hypothesis 1 (H1): Companies run by women and groups with gender diversity will have lower debt levels.

Hypothesis 2 (H2): Companies run by women and groups with gender diversity will enjoy a lower cost of debt.

Hypothesis 3 (H3): Companies run by women and groups with gender diversity will have debt that has longer terms to maturity.

\section{Sample, Data and Methodology}

\subsection{Sample}

The empirical study is carried out by using the SABI database (The Iberian Balance Sheet Analysis System created by Bureau Van Dijk). This database provides accounting information for Spanish and Portuguese companies, obtained from the annual published accounts. Companies belonging to the financial and insurance sectors are excluded.

The sample includes small firms, namely firms that have no more than 50 employees, an annual turnover not exceeding $€ 50$ million, and total assets not exceeding $€ 43$ million (recommendation 2003/361/CE of the European Commission, 6 May 2003). The initial database was filtered to eliminate companies that had negative equity and firms whose total assets or total liabilities were not equal to the sum of their components. In addition, given that our purpose is to analyze the influence of gender in financing, we also removed firms controlled by other companies from our sample. The final data base includes 12,376 start-up companies, founded in 2007, whose first year of life is 2008.

\subsection{Data}

The dependent variables considered are debt (DEBT), the cost of the debt (COSTD) and the maturity of the debt (MATUR). For the model of debt level, the dependent variable is calculated as the ratio of debt to total assets [74]. The cost of debt is computed as the ratio of financial expenses to total debt. The maturity of the debt 
is calculated as the ratio of long-term debt to total debt [4].

To measure the presence of women and gender diversity we employ the following variables: A dummy variable, DWOMEN, which takes the value 1 when the CEO is a woman and 0 when it is a man; ADM, computed as the total number of women on the board divided by the total number of members of the board. Two indices are used to measure gender diversity. On the one hand, the BLAU index is defined as: $1-\sum_{i=1}^{n} P_{i}^{2}$, where $\mathrm{P}_{\mathrm{i}}$ refers to the ratio of women on the board. The values of this index range between 0 and a maximum of 0.5 ; the latter occurs when there is the same percentage of men and women on the board. On the other hand, the SHANNON index is defined as: $-\sum_{i=1}^{n} P_{i} \ln P_{i}$, where $\mathrm{P}_{\mathrm{i}}$ is estimated as in the BLAU index. The values of this index range between 0 and a maximum of 0.69 ; The latter corresponds to the greatest possible diversity [35], [78].

The control variables in relation to the debt model are the following: firms' returns on assets (ROA), measured as the earnings before taxes and financial expenses divided by total assets [39]; the firm size (SIZE), calculated as the natural logarithm of total assets [33]; the tangible assets ratio (FIXED), measured as net tangible assets divided by total assets [33], [68]; the economic risk (ECRISK), computed as the square of the difference of the annual returns of a company and the annual profitability of all businesses, multiplied by the sign of such difference [34]; and the liquidity ratio (LIQ), measured as the working capital divided by total assets [2]. In addition, we consider debt maturity (MATUR) and debt cost (COSTD) which are defined above.

Thus, for the analysis of the debt level we define the following model:

$$
\begin{aligned}
& D E B T_{i}=\beta_{0}+\beta_{1} \text { GEN }_{i}+\beta_{2} \text { MATUR }_{i}+ \\
& +\beta_{3} \text { ROA }_{i}+\beta_{4} \text { SIZE }_{i}+\beta_{5} \text { FIXED }_{i}+ \\
& +\beta_{6} \text { ECRISK }_{i}+\beta_{7} \text { LIQ }_{i}+\beta_{8} \text { COSTD }_{i}+u_{i}
\end{aligned}
$$

where $\mathrm{i}=1, \ldots, \mathrm{n}$, denotes the company and GEN is one of the alternative measures of gender diversity defined above.

The second model examined focuses on the cost of debt (COSTD). It includes as control variables, the firms' size (SIZE); the firms' returns on assets (ROA); the growth opportunities (GROWP), computed as the depreciation of assets divided by total assets [74]; the debt level (DEBT); the debt maturity (MATUR); and the solvency ratio (SOLV), which determines the ability of the company to meet their commitments in the long term, measured as cash flow divided by total assets.

The cost of debt model is defined as follows:

$$
\begin{aligned}
& \operatorname{COSTD}_{i}=\beta_{0}+\beta_{1} \text { GEN }_{i}+\beta_{2} \text { SIZE }_{i}+ \\
& +\beta_{3} \text { ROA }_{i}+\beta_{4} \text { GROWP }_{i}+\beta_{5} \text { SOLV }_{i}+ \\
& +\beta_{6} D E B T_{i}+\beta_{7} \text { MATUR }_{i}++u_{i}
\end{aligned}
$$

where $\mathrm{i}=1, \ldots, \mathrm{n}$, denotes the company and GEN is one of the alternative measures of gender diversity defined above.

The third model focuses on the debt maturity (MATUR). It includes, as control variables, the tangible assets ratio (FIXED); the sales rotation ratio (ROTAT), computed as total sales divided by total assets [2]; the debt level (DEBT); the firms' returns on assets (ROA); the growth opportunities (GROWP); the firm size (SIZE); the liquidity ratio (LIQ); and the cost of debt (COSTD).

The maturity of debt model is defined as follows:

$$
\begin{aligned}
& \text { MATUR }_{i}=\beta_{0}+\beta_{1} G_{E}+\beta_{2} \text { DEBT }_{i}+ \\
& +\beta_{3} \text { ROA }_{i}+\beta_{4} \text { GROWP }_{i}+\beta_{5} \text { FIXED }_{i}+ \\
& +\beta_{6} \text { SIZE }_{i}+\beta_{7} \text { LIQ }_{i}+\beta_{8} \text { ROTAT }_{i}+ \\
& +\beta_{9} \text { COSTD }_{i}++u_{i}
\end{aligned}
$$

where $\mathrm{i}=1, \ldots, \mathrm{n}$, denotes the company and GEN is one of the alternative measures of gender diversity defined above.

Descriptive statistics are presented in Table 1. The mean level of debt (DEBT) is $74.8 \%$, exceeding $60 \%$, the average figure for Spanish companies. The mean of the cost of debt (COSTD) is $3.5 \%$. It must be highlighted that the sample examined includes micro and small firms that usually get their funds from bank credit [7], their own finance or from family and friends and, especially, microcredits. The mean of the debt maturity (MATUR) is $21.3 \%$, confirming that these firms largely employ short term debt. This may be due to the optimism of the entrepreneur or the greatest risk that the banks run when lending money to such companies [48]. 
Tab. 1: Descriptive statistics

\begin{tabular}{l|c|c|c|c|c}
\multicolumn{1}{c|}{ Variable } & Mean & Median & Standard D. & Minimum & Maximum \\
\hline DEBT & 0.748 & 0.837 & 0.246 & 0.000 & 1.000 \\
\hline COSTD & 0.035 & 0.016 & 0.234 & 0.000 & 12.561 \\
\hline MATUR & 0.213 & 0.053 & 0.283 & 0.000 & 1.000 \\
\hline DWOMEN & 0.210 & 0.000 & 0.428 & 0.000 & 9.000 \\
\hline ADM & 0.190 & 0.000 & 0.356 & 0.000 & 1.000 \\
\hline BLAU & 0.060 & 0.000 & 0.158 & 0.000 & 0.500 \\
\hline SHANNON & 0.079 & 0.000 & 0.216 & 0.000 & 0.693 \\
\hline ROA & -0.144 & 0.028 & 1.797 & -92.059 & 20.263 \\
\hline SIZE & 5.149 & 5.108 & 1.397 & 0.065 & 10.610 \\
\hline FIXED & 0.238 & 0.153 & 0.245 & 0.000 & 1.000 \\
\hline ECRISK & -3.015 & 0.030 & 117.926 & $-8,448.367$ & 416.438 \\
\hline LIQ & -0.177 & 0.015 & 1.989 & -106.740 & 1.000 \\
\hline SOLV & 0.121 & 0.071 & 0.274 & 0.000 & 20.653 \\
\hline GROWP & 0.038 & 0.020 & 0.266 & 0.000 & 1.112 \\
\hline ROTAT & 2.897 & 1.823 & 20.441 & 0.000 & $2,149.829$ \\
\hline
\end{tabular}

Regarding the variables of gender, $21 \%$ of the firms have a woman as CEO. The proportion of women on the board is high, $19 \%$, compared with large companies where the corresponding figure is only close to $5 \%$ [52]. These figures may be related to self-employment as well as to family businesses.

\subsection{Methodology}

The methodology employed is Three Stage Least Squares (3SLS). This methodology controls the endogeneity of the variables, using a system of simultaneous equations [21]. This methodology has been used because of the peculiar characteristics of the sample, composed, as it is, of start-up firms with only a year of life. This circumstance makes it impossible to use a more powerful methodology such as panel data.

\section{Results}

The results of the estimation of Models 1, 2 and 3 are presented in Tables 2, 3 and 4, respectively.

In Table 2 it can be seen that a woman as CEO or the presence of women on the board exerts a significant negative influence on the level of a firm's debt. The same influence is observed when employing diversity indexes (Blau and Shannon indexes). Therefore, the Hypothesis 1 is confirmed: Companies run by women and groups with gender diversity will have lower levels of debt. These results are consistent with most previous research. It may well be that women have greater aversion to risk [64], [9], [75], [41] which influences the firm's debt level. Following the same reasoning, it should be noted that there is a major difficulty for heterogeneous groups to reach agreement. The need to seek consensus often leads to less risky strategies [41]. However, this result could also be explained by discrimination on the supply side, which might result in banks lending less money to companies run by women.

With regard to the control variables, all of them are significant and have a negative relationship with the debt level, with the exception of the risk and the maturity of the debt, which have a significant positive relationship with the debt level. Debt may be used in order to secure tax advantages [67], but there are other tax deductions such as depreciation of fixed assets [26] which could lead to a negative relationship between tangible assets (FIXED) 
Tab. 2: Estimation of model 1 - debt level

\begin{tabular}{|c|c|c|c|c|}
\hline MODEL DEBT & DWOMEN & ADM & BLAU & SHANNON \\
\hline \multirow{2}{*}{ Constant } & $0.195^{\star * *}$ & $0.935^{\star * *}$ & $0.926^{* * *}$ & $0.926^{\star * *}$ \\
\hline & $(16.78)$ & (76.93) & $(74.62)$ & $(77.14)$ \\
\hline \multirow{2}{*}{ GEN } & $-0.030^{* * *}$ & $-0.040^{* * *}$ & $-0.108^{* * *}$ & $-0.078^{* * *}$ \\
\hline & $(-4.24)$ & $(-5.14)$ & $(-6.32)$ & $(-6.46)$ \\
\hline \multirow{2}{*}{ MATUR } & $0.904^{\star \star \star}$ & $0.887^{* \star \star}$ & $0.882^{\star * \star}$ & $0.885^{\star \star \star}$ \\
\hline & (91.11) & $(93.98)$ & $(90.58)$ & $(93.85)$ \\
\hline \multirow{2}{*}{ ROA } & $-0.043^{* * *}$ & $-0.024^{*}$ & $-0.027^{*}$ & $-0.026^{\star *}$ \\
\hline & $(-2.86)$ & $(-1.67)$ & $(-1.87)$ & $(-1.85)$ \\
\hline \multirow{2}{*}{ SIZE } & $-0.006^{* \star}$ & $-0.003^{* * *}$ & $-0.007^{* * *}$ & $-0.006^{* \star *}$ \\
\hline & $(-2.32)$ & $(-3.62)$ & $(-3.05)$ & $(-2.84)$ \\
\hline \multirow{2}{*}{ FIXED } & $-0.719^{* * *}$ & $-0.750^{\star \star \star}$ & $-0.742^{* * *}$ & $-0.748^{\star * *}$ \\
\hline & $(-59.21)$ & $(-64.65)$ & $(-62.37)$ & $(-64.65)$ \\
\hline \multirow{2}{*}{ ECRISK } & $0.004^{* * *}$ & $0.003^{* * *}$ & $0.003^{* * *}$ & $0.003^{* * *}$ \\
\hline & $(5.66)$ & $(4.26)$ & $(4.15)$ & $(4.44)$ \\
\hline \multirow{2}{*}{ LIQ } & $-0675^{\star \star \star}$ & $-0.704^{\star \star *}$ & $-0.696^{\star * *}$ & $-0.701^{\star \star *}$ \\
\hline & $(-64.47)$ & $(-71.08)$ & $(-68.50)$ & $(-70.89)$ \\
\hline \multirow{2}{*}{ COSTD } & $-2.163^{\star * *}$ & $-1.924^{* * *}$ & $-1.862^{* * *}$ & $-1.929^{* * *}$ \\
\hline & $(-41.35)$ & $(-39.83)$ & $(-38.85)$ & $(-40.02)$ \\
\hline
\end{tabular}

\begin{tabular}{l|c|c|c|c}
\hline R2 & -2.278 & -1.613 & -1.583 & -1.621 \\
\hline X2 & $11,306.62^{\star \star *}$ & $12,295.33^{\star * *}$ & $11,518.00^{\star * *}$ & $12,299.31^{\star * *}$ \\
\hline Obs. & 6,782 & 7,316 & 6,906 & 7,316 \\
\hline
\end{tabular}

z-Statistic in parenthesis

* Significant at the $90 \%$ level, ${ }^{* *}$ Significant at the $95 \%$ level and ${ }^{* * *}$ Significant at the $99 \%$ level.

$\mathrm{X} 2-$ Test of explanatory variables

Source: [2]

and the debt level that we find in Table 2. Firm size [80] and liquidity also leads to reduced levels of debt.

In Table 3 the results related to the cost of debt can be found. We find a significant negative influence of the different variables relating to the presence of women and gender diversity on the cost of debt. This result does not support the argument that there is possible discrimination on the part of those who offer funds to women. On the contrary, it would support the argument that the presence of women in decision making may reduce risk that the firm is exposed to, leading to a lower cost of debt [62]. Therefore, Hypothesis $2(\mathrm{H} 2)$ is confirmed: Companies run by women and groups with gender diversity will enjoy a lower cost of debt.
Regarding the control variables, we observe a negative influence of firms' returns on assets and the maturity of debt on the cost of the debt. Normally, longer terms of debt maturity lead to lower interest rates [7] and larger returns. On the other hand, we observe a positive effect of debt level, firm size and solvency ratio on the cost of debt. This last result may be consequence of the fact that more solvent firms have increased access to debt [81] and, therefore, bear higher costs.

In Table 4 we observe that the presence of women on the board or as CEO leads to longer terms of debt maturity. We also observe that gender-diverse boards use longer term debt. Therefore, Hypothesis $3(\mathrm{H} 3)$ is confirmed: Companies run by women and groups with 
Tab. 3: Estimation of model 2 - cost of the debt

\begin{tabular}{|c|c|c|c|c|}
\hline MODEL COSTD & DEWOMEN & ADM & BLAU & SHANNON \\
\hline \multirow{2}{*}{ Constant } & $0.195^{\star * *}$ & $0.191^{* * *}$ & $0.194^{\star * *}$ & $0.187^{* * *}$ \\
\hline & $(16.78)$ & $(17.08)$ & $(16.63)$ & $(166.99)$ \\
\hline \multirow{2}{*}{ GEN } & $-0.016^{* * *}$ & $-0.021^{* * *}$ & $-0.108^{* * *}$ & $-0.043^{* * *}$ \\
\hline & $(-3.04)$ & $(-3.45)$ & $(-6.32)$ & $(-4.45)$ \\
\hline \multirow{2}{*}{ SIZE } & 0.002 & $0.003^{*}$ & $0.003^{* *}$ & $0.004^{* *}$ \\
\hline & $(1.02)$ & $(1.67)$ & $(1.97)$ & $(2.18)$ \\
\hline \multirow{2}{*}{ ROA } & $-0.377^{* * *}$ & $-0.289^{* \star *}$ & $-0.279^{* * *}$ & $-0.292^{* \star *}$ \\
\hline & $(-11.11)$ & $(-8.57)$ & $(-7.94)$ & $(-8.68)$ \\
\hline \multirow{2}{*}{ GROWP } & -0.062 & 0.056 & 0.071 & 0.051 \\
\hline & $(-1.31)$ & $(1.17)$ & $(1.41)$ & $(1.07)$ \\
\hline \multirow{2}{*}{ SOLV } & $0.391^{* \star *}$ & $0.300^{\star * *}$ & $0.288^{* * *}$ & $0.302^{* * *}$ \\
\hline & $(11.10)$ & $(8.56)$ & $(7.90)$ & $(8.65)$ \\
\hline \multirow{2}{*}{ DEBT } & $1.803^{\star \star \star}$ & $1.617^{\star \star \star}$ & $1.660^{\star * \star}$ & $1.614^{\star \star *}$ \\
\hline & $(29.20)$ & $(26.94)$ & $(26.19)$ & $(26.93)$ \\
\hline \multirow{2}{*}{ MATUR } & $-2.219^{\star * *}$ & $-2.212^{* * *}$ & $-2.296^{* * *}$ & $-2.217^{* * *}$ \\
\hline & $(-36.82)$ & $(-37.35)$ & $(-36.86)$ & $(-37.47)$ \\
\hline
\end{tabular}

\begin{tabular}{l|c|c|c|c}
\hline R2 & -0.203 & -0.178 & -0.176 & -0.178 \\
\hline $\mathbf{X 2}$ & $2,607.64^{* \star *}$ & $2,466.64^{\star * *}$ & $2,341.10^{\star \star *}$ & $2,475.17^{\star * *}$ \\
\hline Obs. & 6,782 & 7,316 & 6,906 & 7,316 \\
\hline
\end{tabular}

z-Statistic in parenthesis

* Significant at the $90 \%$ level, ${ }^{* *}$ Significant at the $95 \%$ level and ${ }^{* *}$ Significant at the $99 \%$ level.

$\mathrm{X} 2$-Test of explanatory variables.

gender diversity will have debt that has longer terms to maturity.

In terms of the control variables, the level of debt, the tangible assets, the size of the firm, liquidity and the cost of debt have significant positive influence on the debt maturity [43], [28]. The influence of the growth opportunities [59] and sales rotation is negative.

\section{Conclusions}

Gender and its influence on different variables of the firm have been attracting the attention of researchers. Several papers have indicated differences in the way that men and women run businesses and the influence of gender diversity in working groups. Most of these studies have examined the influence of gender diversity on firm value or firm risk. However, there are not many studies examining the influence of women on the financial decisions of the firm, especially for small companies. Small firms are characterized by having very limited access to funding sources, and depending heavily on bank financing.

Research on gender diversity has been increasing in recent years. The emergence of gender equality laws in many countries, including Spain, has helped this phenomenon. Several laws have been adopted in Spain to provide equal opportunities to women. The Código Unificado de Buen Gobierno (Unified Code of Good Governance) recommends positive discrimination for women in Article 15 , in order to balance the numbers of men and women on boards. The Ley de Igualdad (Gender Equality Act) requires a $40 \%$ female representation on boards of directors of companies with more than 250 employees, 
Tab. 4: Estimation of model 3-maturity of the debt

\begin{tabular}{|c|c|c|c|c|}
\hline MODEL MATUR & DWOMEN & ADM & BLAU & SHANNON \\
\hline \multirow{2}{*}{ Constant } & $-0.943^{* * *}$ & $-0.965^{\star \star \star}$ & $-0.959^{* * *}$ & $-0.957^{\star * *}$ \\
\hline & $(-70.10)$ & $(-77.63)$ & $(-75.37)$ & $(-77.81)$ \\
\hline \multirow{2}{*}{ GEN } & $0.025^{\star * *}$ & $0.034^{* * *}$ & $0.081^{* * *}$ & $0.059^{\star * *}$ \\
\hline & $(4.49)$ & $(5.48)$ & $(5.94)$ & $(6.10)$ \\
\hline \multirow{2}{*}{ DEBT } & $0.957^{* * *}$ & $0.953^{* * *}$ & $0.955^{\star \star *}$ & $0.954^{* * *}$ \\
\hline & $(106.18)$ & $(111.55)$ & $(107.35)$ & $(111.41)$ \\
\hline \multirow{2}{*}{ ROA } & -0.007 & $-0.019^{*}$ & -0.014 & $-0.018^{*}$ \\
\hline & $(-0.61)$ & $(-1.86)$ & $(-1.28)$ & $(-1.69)$ \\
\hline \multirow{2}{*}{ GROWP } & $-0.430^{* \star *}$ & $-0.419^{\star * *}$ & $-0.418^{\star \star *}$ & $-0.423^{* * *}$ \\
\hline & $(-11.76)$ & $(-11.74)$ & $(-11.30)$ & $(-11.86)$ \\
\hline \multirow{2}{*}{ FIXED } & $0.871^{* \star *}$ & $0.903^{* \star *}$ & $0.903^{* * *}$ & $0.905^{\star * *}$ \\
\hline & $(81.84)$ & $(90.71)$ & $(87.92)$ & (90.93) \\
\hline \multirow{2}{*}{ SIZE } & $0.012^{* * *}$ & $0.016^{* * *}$ & $0.015^{\star * \star}$ & $0.015^{\star \star *}$ \\
\hline & $(6.47)$ & $(9.24)$ & $(8.49)$ & $(8.44)$ \\
\hline \multirow{2}{*}{ LIQ } & $0.808^{* * *}$ & $0.837^{\star \star \star}$ & $0.835^{\star \star \star}$ & $0.837^{\star \star \star}$ \\
\hline & $(81.94)$ & $(90.56)$ & $(87.53)$ & $(90.48)$ \\
\hline \multirow{2}{*}{ ROTAT } & $-0.002^{* * *}$ & $-0.001^{* *}$ & $-0.001^{* *}$ & $-0.001^{* *}$ \\
\hline & $(-3.08)$ & $(-2.18)$ & $(-2.21)$ & $(-2.36)$ \\
\hline \multirow{2}{*}{ COSTD } & $1.737^{* * *}$ & $1.504^{* * *}$ & $1.454^{* * *}$ & $1.508^{\star * *}$ \\
\hline & $(36.04)$ & (34.32) & $(33.13)$ & $(34.40)$ \\
\hline R2 & -0.686 & -0.309 & -0.298 & -0.313 \\
\hline $\mathbf{F}$ & $15,337.66^{* * *}$ & $17,765.38^{* \star *}$ & $16,556.80^{\star \star \star}$ & $17,717.96^{\star \star *}$ \\
\hline Obs. & 6,782 & 7,316 & 6,906 & 7,316 \\
\hline
\end{tabular}

z-Statistic in parenthesis

* Significant at the $90 \%$ level, ${ }^{* *}$ Significant at the $95 \%$ level and ${ }^{* * *}$ Significant at the $99 \%$ level.

$\mathrm{X} 2$-Test of explanatory variables

Source: [2]

if they are to bid for public sector contracts. However, these and other rules have focused on large companies and not on small firms, which are more numerous and generate most of the employment in Spain.

This article examines the influence of gender on some financial decisions of Spanish micro and small start-up enterprises. These firms have larger problems securing funding and the characteristics of the owners and managers are crucial to obtaining financing, as well as the characteristics of specific projects. In contrast with previous papers, the present study examines not only the level of debt but also two other relevant finance variables: the cost of the debt and the maturity of debt. All this is examined in the Spanish context, characterized by a dominant presence of bank financing.

For the sample examined, only $21 \%$ of CEOs are women and the percentage of female directors is $19 \%$. These values are far to the objective of gender equality on top management positions of small start-up enterprises but are much larger than the figures for Spanish listed firms. The family ties and the greater possibility of create micro firms by women may explain these values. 
The results show that the presence of women, as CEOs or as members of boards of directors, leads to lower debt financing. The results also show that the presence of women influences the companies in such a way that they have lower debt cost and higher debt maturity. These results are also seen where the boards are more gender-diverse. All this evidence supports the hypothesis that women are more averse to risk, while suggesting that there is little discrimination on the part of suppliers of credit.

This study can present both theoretical and empirical implications. We provide arguments relative to the effects of gender diversity not only on debt behavior but also on other financial decision as debt cost and maturity. Therefore, we show that gender diversity can affect to the management of small firms. In this way, it can be interesting to extend the recommendations about equality to this type of firms. We find that gender diversity reduces the debt ratio and the cost of the debt and increases the debt maturity. So, women can improve the financial situation and the firm stability in a crisis context. In this way, to promote women to top management positions of firm is not only adequate for ethical reasons but also for effectiveness.

This research is part of the project FEM2013-40578-P financed by the Ministerio de Economía y Competitividad (Government of Spain). We also acknowledge support from Fundación CajaMurcia.

\section{References}

[1] AGRAWAL, A. and KNOEBER, C.R. Firm performance and mechanisms to control agency problems between managers and shareholders. Journal of Financial and Quantitative Analysis. 1996, Vol. 31, Iss. 3, pp. 377-397. ISSN 00221090. DOI: $10.2307 / 2331397$.

[2] ALTMAN, E.I. Financial ratios, discriminant analysis, and the prediction of corporate bankruptcy. The Journal of Finance. 1968, Vol. 23, Iss. 4, pp. 589-609. ISSN 1540-6261. DOI: 10.1111/j.1540-6261.1968.tb00843.x.

[3] ANG, J.S., CHUA, J.H., McCONNELL, J.J. The administrative cost of corporate bankruptcy: a note. The Journal of Finance. 1982, Vol. 37, Iss. 2, pp. 219-226. ISSN 1540-6261. DOI: 10.1111/j.1540-6261.1982.tb01104.x.

[4] ANTONIOU, A., GUNEY, Y., PAUDYAL, K. The determinants of debt maturity structure:
Evidence from France, Germany and the UK. European Financial Management. 2006, Vol. 12, Iss. 2, pp. 161-194. ISSN 1468-036X. DOI: 10.1111/j.1354-7798.2006.00315.x.

[5] APPELBAUM, S.H., AUDET, L., MILLER, J.C. Gender and leadership? A journey through the landscape of theories. Leadership and Organization Development Journal. 2003, Vol. 24, Iss. 1, pp. 43-51. ISSN 0143-7739. DOI: 10.1108/01437730310457320.

[6] BAXTER, N.D. Leverage, risk of ruin and the cost of capital. The Journal of Finance. 1977, Vol. 22, Iss. 3, pp. 395-403. ISSN 1540-6261. DOI: 10.1111/j.1540-6261.1967.tb02975.x.

[7] BERGER, A., UDELL, G. The economics of small business finance: The roles of private equity and debt markets in the financial growth cycle. Journal of Banking and Finance. 1998, Vol. 22, Iss. 6-8, pp. 613-673. ISSN 0378-4266. DOI: 10.1016/s0378-4266(98)00038-7.

[8] BLAU, P. Inequality and heterogeneity. New York: The Free Press, 1977. ISBN 0-02903660-7. DOI: 10.1093/sf/58.2.677.

[9] BORGHANS, L., et al. Gender differences in risk aversion and ambiguity aversion. IZA Discussion Paper no 3985, 2009. ISSN 15424774. DOI: $10.3386 / w 14713$.

[10] BOYD, B.K. Board control and CEO compensation. Strategic Management Journal. 1994, Vol. 15, Iss. 5, pp. 335-344. ISSN $1097-$ 0266. DOI: $10.1002 / \mathrm{smj} .4250150502$.

[11] BROWN, S.A., SEGAL, P. Female entrepreneurs in profile. Toronto: Canadian Banker, 1989, July-August, pp. 32-34. ISSN 0822-6830.

[12] BRUSH, C. Research on women business owners: Past trends, a new perspective and future directions. Entrepreneurship Theory and Practice. 1992, Vol. 16, Iss. 4, pp. 5-26. ISSN 1540-6520.

[13] BRUSH, C., BIRD, B. Leadership vision of successful women entrepreneurs: Dimensions and characteristics (Summary). Frontiers of Entrepreneurship Research. Wellesley Mass: Center for Entrepreneurial Studies, Babson College, 1996. pp. 100-101. ISSN 0740-7416.

[14] BUCKALEW, E., et al. The future of female CEOs and their glass ceiling. Journal of Business Studies Quarterly. 2012, Vol. 3, Iss. 4, pp. 145-153. ISSN 2156-8626.

[15] BUREAU OF LABOR STATISTICS. Employed persons by detailed occupation, sex, race, and Hispanic or Latino ethnicity [online]. Washington: United Stated Department of 
Labor, 2009 [cit. 2012-12-16]. Available from: http://www.bls.gov/cps/cpsaat11.pdf.

[16] BUTTNER, H., ROSEN, B. Bank loan officers' perceptions of the characteristics of men, women, and successful entrepreneurs. Journal of Business Venturing. 1988, Vol. 3, Iss. 3, pp. 249-258. ISSN 0883-9026. DOI: 10.1016/0883-9026(88)90018-3.

[17] BUTTNER, E., ROSEN, B. Funding new business ventures: Are decision makers biased against women? Journal of Business Venturing. 1989, Vol. 4, Iss. 4, pp. 249-261. ISSN 08839026. DOI: 10.1016/0883-9026(89)90015-3.

[18] CATALYST. Women CEOs of the Fortune 1000 [online]. New York: Catalyst Organization, 2012 [cit. 2013-04-16]. Available from: http:// www.catalyst.org/publication/271/women-ceosof-the-fortune-1000.

[19] CARTER, S., CANNON, T. Women as entrepreneurs. London: Academic Press, 1992. ISBN 0-12-161755-6.

[20] CHAGANTI, R. Management in women owned enterprises. Journal of Small Business Management. 1986, Vol. 24, Iss: October, pp. 18-29. ISSN 1540-627X.

[21] CHAMBERLAIN, G. Multivariate regression models for Panel Data. Journal of Econometrics. 1982, Vol. 18, Iss. 1, pp. 5-46. ISSN 0304-4076. DOI: 10.1016/0304-4076(82)90094-x.

[22] CHANDLER, G., HANKS, S. An investigation of New Venture Teams in emerging businesses. In: REYNOLDS, P., et al. (Ed.). Frontiers of Entrepreneurship Research. Babson Park, MA: Babson College, 1998. ISSN 0740-7416.

[23] COLleRETT, P., AUBRY, P.G. Socioeconomic evolution of women business owners in Quebec. Journal of Business Ethics. 1990, Vol. 9, Iss. 4, pp. 417-422. ISSN 1573-0697. DOI: $10.1007 / \mathrm{bf00380340.}$

[24] CORPORATE WOMEN DIRECTORS INTERNATIONAL REPORT. Women board directors of the Fortune Global 200 [online]. Washington, DC: Globewomen, 2007 [cit. 201212-22]. Available from: http://www.globewomen. org/CWDI/CWDI.htm.

[25] DAILY, C., CERTO, S., DALTON, D. A decade of corporate women: Some progress in the boardroom, none in executive suite. Strategic Management Journal. 1999, Vol. 20, Iss. 1, pp. 93-99. ISSN 1097-0266. DOI: 10.1002/(sici)1097-0266(199901)20:1<93::aidsmj18>3.0.co;2-7.

[26] DeANGELO, H., MASULIS, R. Optimal capital structure under corporate and personal taxation. Journal of Financial Economics. 1980, Vol. 8, Iss. 1, pp. 3-29. ISSN 0304-405X. DOI: 10.1016/0304-405x(80)90019-7.

[27] DIAMOND, D.W. Reputation acquisition in debt markets. Journal of Political Economy. 1989, Vol. 97, Iss. 4, pp. 828-862. ISSN 1537534X. DOI: 10.1086/261630.

[28] DIAMOND, D. Debt maturity structure and liquidity risk. Quarterly Journal of Economics. 1991, Vol. 106, Iss. 3, pp. 709-737. ISSN 15314650. DOI: $10.2307 / 2937924$.

[29] DONALDSON, G. Corporate debt capacity: A study of corporate debt policy and the determination of corporate debt capacity. Harvard: Graduate School of Business Administration, 1961. ISBN 1-58798-034-7. DOI: $10.2307 / 2977084$.

[30] FAMA, E. Agency problems and the theory of the firm. Journal of Political Economy. 1980, Vol. 88, Iss. 2, pp. 288-307. ISSN 1537-534X. DOI: $10.1086 / 260866$.

[31] FAMA, E. What's different about banks? Journal of Monetary Economics. 1985, Vol. 15, Iss. 1, pp. 29-36. ISSN 0304-3932. DOI: 10.1016/0304-3932(85)90051-0.

[32] FARRELL, K., HERSCH, P. Additions to corporate boards: the effect of gender. Journal of Corporate Finance. 2005, Vol. 11, Iss. 1-2, pp. 85-206. ISSN 0929-1199. DOI: 10.1016/j. jcorpfin.2003.12.001.

[33] FATTOUH, B., SCARMOZZINO, P., HARRIS, L. Non-linearity in the determinants of capital structure: Evidence from UK firms. Empirical Economics. 2008, Vol. 34, Iss. 3, pp. 417-438. ISSN 1435-8921. DOI: 10.1007/ s00181-007-0128-3.

[34] GAUD, P., et al. The capital structure of Swiss companies: an empirical analysis using dynamic panel data. European Financial Management. 2005, Vol. 11, Iss. 1, pp. 51-63. ISSN 1468-036X. DOI: 10.1111/j.1354-7798.2005.00275.x.

[35] HARRISON, D.A., KLEIN, K.J. What's the difference? Diversity constructs as separation, variety, or disparity in organizations. Academy of Management Review. 2007, Vol. 32, Iss. 4, pp. 1199-1228. ISSN 1930-3807. DOI: 10.5465/ amr.2007.26586096.

[36] HEIDRICK \& STRUGGLES. Corporate governance in Europe: raising the bar: 2007 Report, 2007. ISBN 1-84980-219-X.

[37] HOLMES, S. An empirical analysis of the financial structure of small and large Australian manufacturing enterprises. Journal of Small 
Business Finance. 2008, Vol. 1, Iss. 2, pp. 141154. ISSN 1057-2287.

[38] JACOBSON, W.S., PALUS, C.K., BOWLING, C.J. A woman's touch? Gendered management and performance in state administration. Journal of Public Administration Research \& Theory. 2010, Vol. 20, Iss. 2, pp. 477-504. ISSN 1477-9803. DOI: 10.1093/ jopart/mup017.

[39] JENSEN, M. Agency costs of free cash flow, corporate finance, and takeovers. The American Economic Review. 1986, Vol. 76, Iss. 2, pp. 323-329. ISSN 0002-8282. DOI: 10.2139/ ssrn.99580.

[40] JENSEN, M.C., MECKLING, W.C. Theory of the firm: Managerial behaviour, agency costs and ownership structure. Journal of Financial Economics. 1976, Vol. 3, Iss. 4, pp. 305-360. ISSN 0304-405X. DOI: 10.2139/ssrn.94043.

[41] JIANAKOPLOS, N., BERNASEK, A. Are women more risk averse? Economic Inquiry. 1998, Vol. 36, Iss. 4, pp. 620-630. ISSN 14657295. DOI: 10.1111/j.1465-7295.1998.tb01740.x. [42] JUDGE, W.Q., ZEITHAML, C. Institutional and strategic choice perspectives on board involvement in the strategic decision process. Academy of Management Journal. 1992, Vol. 35, Iss. 4, pp. 766-794. ISSN 1948-0989. DOI: 10.2307/256315.

[43] JUN, S., JEN, F. Trade-off model on debt maturity structure. Review of Quantitative Finance and Accounting. 2003, Vol. 20, Iss. 1, pp. 5-34. ISSN 1573-7179. DOI: 10.1023/A:1022190205033.

[44] KALLENBERG, A., LEICHT, K. Gender and organizational performance: determinants of small business survival and success. Academy of Management Journal. 1991, Vol. 34, Iss. 1, pp. 136-161. ISSN 1948-0989. DOI: 10.2307/256305.

[45] KESNER, I. Directors' characteristics and committee membership: and investigation of type, occupation, tenure and gender. Academy of Management Journal. 1998, Vol. 31, Iss. 1, pp. 66-88. ISSN 1948-0989. DOI: 10.2307/256498.

[46] LA PORTA, R., et al. Law and finance. Journal of Political Economy. 1998, Vol. 106, Iss. 6, pp. 1113-1155. ISSN 1537-534X.

[47] LA PORTA, R., et al. Investor protection and corporate valuation. Journal of Finance. 2002, Vol. 57, Iss. 3, pp. 1147-1170. ISSN 1540-6261. DOI: 10.1111/1540-6261.00457.

[48] LANDIER, A., THESMAR, D. Financial contracting with optimistic entrepreneurs. The
Review of Financial Studies. 2009, Vol. 22, Iss. 1, pp. 117-150. ISSN 1465-7368. DOI: 10.1093/rfs/hhn065.

[49] LERNER, M., BRUSH, C., HISRICH, R. Israeli women entrepreneurs: An examination of factors affecting performance. Journal of Business Venturing. 1997, Vol. 12, Iss. 4, pp. 315-339. ISSN 0883-9026. DOI: 10.1016/ s0883-9026(96)00061-4.

[50] LODEN, M. Feminine leadership, or how to succeed in business without being one of the boys. New York: Times Books, 1985. ISBN 0-81291-240-3.

[51] LOSCOCCO, K., ROBINSON, J. Barriers to women's small-business success in the United States. Gender and Society. 1991, Vol. 5, Iss. 4, pp. 511-532. ISSN 1552-3977. DOI: 10.1177/089124391005004005.

[52] LUCASPEREZ,M.E., etal.Femaledirectors and top managers' pay: Evidence from Spain. In: 18th International Scientific Conference in Economics and Management [online]. Kaunas, 2013 [cit. 2013-05-02]. Available from: http:// www.ebooks.ktu.It/einfo/1044/economics_and_ management_\%E2\%80\%93_2013.

[53] MILLER, M.H. Debt and taxes. Journal of Finance. 1977, Vol. 32, Iss. 2, pp. 261275. ISSN 1540-6261. DOI: 10.1111/j.15406261.1977.tb03267.x.

[54] MODIGLIANI, F., MILLER, M.H. The cost of capital, corporation finance, and the theory of investment. The American Economic Review. 1958, Vol. 48, Iss. 3, pp. 261-297. ISSN 00028282.

[55] MODIGLIANI, F., MILLER, M. Corporate income taxes and the cost of capital: a correction. The American Economic Review. 1963, Vol. 53, Iss. 2, pp. 433-443. ISSN 0002-8282.

[56] MOHR, G., WOLFRAM, H.J. Leadership and effectiveness in the context of gender: The role of leaders' verbal behaviour. British Journal of Management. 2008, Vol. 19, Iss. 1, pp. 4-16. ISSN 1467-8551. DOI: 10.1111/j.14678551.2007.00521.x.

[57] MORRISON, A. The new leaders: Guidelines on leadership diversity in America. San Francisco: Jossey-Bsass, 1992. ISBN 1-55542-459-7. DOI: 10.2307/3381052.

[58] MURAVYEV, A., TALAVERA, O., SCHÄFER, D. Entrepreneurs' gender and financial constraints: Evidence from International Data. Journal of Comparative Economics. 2009, Vol. 37, Iss. 2, pp. 270-286. ISSN 0147-5967. DOI: 10.1016/j.jce.2008.12.001. 
[59] MYERS, S.C. Determinants of corporate borrowing. Journal of Financial Economics. 1977, Vol. 5, Iss. 2, pp. 147-175. ISSN 1537534X. DOI: 10.1016/0304-405x(77)90015-0.

[60] MYERS, S.C., MAJLUF, N. Corporate financing and investment decisions when firms have information that investors do not have. Journal of Financial Economics. 1984, Vol. 13, Iss. 2, pp. 187-221. ISSN 1537-534X. DOI: 10.1016/0304-405X(84)90023-0.

[61] NIELSEN, S., HUSE, M. Women director's contribution to board decision-making and strategic involvement: The role of equality perception. European Management Review. 2010, Vol. 7, Iss. 1, pp. 16-29. ISSN 1740-4762. DOI: $10.1057 / \mathrm{emr} .2009 .27$.

[62] OLSEN, R., COX, C. The influence of gender on the perception and response to investment risk: The case of professional investors. Journal of Psychology and Financial Markets. 2001, Vol. 2, Iss. 1, pp. 29-36. ISSN 1520-8834. DOI: 10.1207/ s15327760jpfm0201_3.

[63] OLSEN, S.F., CURRIE, H.M. Female entrepreneurs: Personal value systems and business strategies in a male dominated industry. Journal of Small Business Management. 1992, Vol. 30, Iss. 1, pp. 49-57. ISSN 1540-627X.

[64] ORSER, B., RIDING, A., MANLEY, K. Women entrepreneurs and financial capital. Entrepreneurship Theory and Practice. 2006, Vol. 30, Iss. 5, pp. 643-665. ISSN 1540-6520. DOI: 10.1111/j.1540-6520.2006.00140.x.

[65] OZKAN, A. An empirical analysis of corporate debt maturity structure. European Financial Management. 2000, Vol. 6, Iss. 2, pp. 197-212. ISSN 1468-036X. DOI: 10.1111/1468036x.00120.

[66] OZKAN, A. The determinants of corporate debt maturity: Evidence from UK firms. Applied Financial Economics. 2002, Vol. 12, Iss. 1, pp. 19-24. ISSN 1466-4305. DOI: 10.1080/09603100110102691.

[67] PETTIT, R., SINGER, R. Small business finance: a research agenda. Financial Management. 1985, Vol. 14, Iss. 3, pp. 47-60. ISSN 1468-036X. DOI: 10.2307/3665059.

[68] PRÁŠILOVÁ, P. Determinanty kapitálové struktury českých podniků. E+M Ekonomie a Management. 2012, Vol. 15, Iss. 1, pp. 89104. ISSN 1212-3609.

[69] RAJAN, R., ZINGALES, L. What do we know about capital structure? Some evidence from international data. The Journal of Finance. 1995, Vol. 50, Iss. 5, pp. 1421-1460. ISSN 1540-6261. DOI: 10.1111/j.1540-6261.1995.tb05184.x.

[70] ROBINSON, G., DECHANT, K. Building a business case for Diversity. Academy of Management Executive. 1997, Vol. 11, Iss. 3, pp. 21-30. ISSN 1079-5545. DOI: 10.5465/ ame.1997.9709231661.

[71] ROMANI, G., ATIENZA, M., AMORÓS, J.E. Informal investors in Chile: an exploratory study from a gender perspective. Journal of Business Economics and Management. 2012, Vol. 13, Iss. 1, pp. 111-131. ISSN 2029-4433. DOI: 10.3846/16111699.2011.620141.

[72] ROPER, S., SCOTT, J.M. Perceived Financial Barriers and the Start-up Decision An Econometric Analysis of Gender Differences Using GEM Data. International Small Business Journal. 2009, Vol. 27, Iss. 2, pp. 149-171. ISSN 1741-2870. DOI: $10.1177 / 0266242608100488$. [73] SÁNCHEZ-VIDAL, J., MARTÍN-UGEDO, J.F. Are the implications of the financial growth cycle confirmed for Spanish SME's? Journal of Business Economics and Management. 2012, Vol. 13, Iss. 4, pp. 637-665. ISSN 2029-4433. DOI: 10.3846/16111699.2011.620161.

[74] SCHERR, F., HULBURT, H. The debt maturity structure of small firms. Financial Management. 2001, Vol. 30, Iss. 8, pp. 85-111. ISSN 1468-036X. DOI: 10.2307/3666392.

[75] SCHERR, F., SUGRUE, T., WARD, J. Financing the small firm start-up: determinants of debt use. The Journal of Small Business Finance. 1993, Vol. 1, Iss. 1, pp. 17-36. ISSN 1057-2287.

[76] SMITH, N., SMITH, V., VERNER, M. Do women in top management affect firm performance? A panel study of 2,500 Danish firms. International Journal of Productivity and Performance Management. 2006, Vol. 55, Iss. 7, pp. 569-593. ISSN 1741-0401. DOI: 10.1108/17410400610702160.

[77] SOLTANE, B. Governance and performance of microfinance institutions in Mediterranean countries. Journal of Business Economics and Management. 2009, Vol. 10, Iss. 1, pp. 31-43. ISSN 2029-4433. DOI: 10.3846/1611-1699.2009.10.31-43.

[78] STIRLING, A. On the economics and analysis of diversity. Science Policy Research Unit (SPRU) [online]. Pennsylvania: Penn State University, 1998 [cit. 2013-12-24]. Electronic Working Papers Series. Vol. 28. 156 p. (PDF). Available from: http://citeseerx.ist.psu.edu/ 
viewdoc/download?doi=10.1.1.144.8865\&rep= rep $1 \&$ type $=$ pdf.

[79] TERJESEN, S., SEALY, R., SINGH, V. Women directors on Corporate boards: A review and research agenda. Corporate Governance: An International Review. 2009, Vol. 17, Iss. 3, pp. 320-337. ISSN 1467-8683. DOI: 10.1111/j.1467-8683.2009.00742.x.

[80] TITMAN, S., WESSELS, R. The determinants of capital structure choice. Journal of Finance. 1988, Vol. 43, Iss. 1, pp. 1-19. ISSN 1540-6261. DOI: 10.1111/j.15406261.1988.tb02585.x.

[81] VERHEUL, I., THURIK, R. Start-up capital: Does gender matter? Small Business Economics. 2001, Vol. 16, Iss. 4, pp. 329-346. ISSN 1573-0913.

[82] VIEITO, J.P.T. Gender, top management compensation gap, and company performance: Tournament versus behavioural theory. Corporate Governance: An International Review. 2012, Vol. 20, Iss. 1, pp. 46-63. ISSN 1467-8683. DOI: 10.1111/j.14678683.2011.00878.x.

[83] WARNER, J.B. Bankruptcy costs: Some evidence. Journal of Finance. 1977, Vol. 32, Iss. 2, pp. 337-347. ISSN 1540-6261. DOI: 10.1111/j.1540-6261.1977.tb03274.x.

[84] WEISBACH, M.S. Outside directors and CEO turnover. Journal of Financial Economics. 1988, Vol. 20, Iss. January-March, pp. 431-
460. ISSN 1537-534X. DOI: 10.1016/0304405x(88)90053-0.

[85] WIJST, D.V. Financial structure in small business. Theory, Tests and Applications. Berlin: Ed. Springer-Verlag, 1989. ISBN 3-54050-574-1.

[86] ZELECHOWSKI, D., BILIMORIA, D. Characteristics of women and men corporate inside directors. Corporate Governance: An International Review. 2004, Vol. 12, Iss. 3, pp. 337-342. ISSN 1467-8683. DOI: 10.1111/j.14678683.2004.00374.x.

Carmen Maria Hernandez-Nicolas, Ph D Universidad de Murcia Departamento de Organización de Empresas y Finanzas cm.hernandeznicolas@um.es

Prof. Juan Francisco Martín-Ugedo, Ph D Universidad de Murcia Departamento de Organización de Empresas y Finanzas juanfran@um.es

Prof. Antonio Mínguez-Vera, Ph D Universidad de Murcia Departamento de Organización de Empresas y Finanzas minver@um.es 


\section{THE INFLUENCE OF GENDER ON FINANCIAL DECISIONS: EVIDENCE FROM SMALL START-UP FIRMS IN SPAIN}

\section{Carmen Maria Hernandez-Nicolas, Juan Francisco Martín-Ugedo, Antonio Mínguez-Vera}

The presence of women in management positions in companies is one of the topics that have generated the most interest and controversy over recent years. This has also been the case in Spain, where several legal initiatives have promoted the presence of women on decision-making bodies of companies. These important and pioneering legislative initiatives focus on the recommendation of positive discrimination in favour of women in large firms. This measure is justified not only for reasons of ethics or social justice, but also for the purposes of efficiency and rational economic behaviour. These laws have created an open debate in Spain and in other countries where they have been enacted and they have attracted the attention of researchers. In this context, the majority of the studies have attempted to analyse the effect of gender diversity among top managers on corporate performance of listed firms. On the contrary, this paper analyses the influence of gender on some financial decisions, using a sample of 12,376 Spanish small and micro start-up firms. Unlike previous papers, this manuscript examines not only the level of debt but also the cost and maturity of the debt. To control the endogeneity of the variables, a system of simultaneous equation with Three Stage Least Squares methodology is employed. The results show that companies run by women and boards with gender diversity tend to borrow less, have lower costs for debt and longer term debt, reinforcing the hypothesis that females are more risk averse. These results are robust for diverse measures of gender diversity (the presence of a woman as CEO, the percentage of female directors and Blau and Shannon diversity indexes).

Key Words: Gender, financial decisions, small firms, start-ups.

JEL Classification: G32, J16, M00.

DOI: 10.15240/tul/001/2015-4-007 